\title{
The Generation Z Readiness for Industrial Revolution 4.0
}

\author{
Syuhada Yunos ${ }^{1}$, Rosseni Din² \\ ${ }^{1}$ Faculty of Education, Universiti Kebangsaan Malaysia, Bangi, Selangor, Malaysia \\ ${ }^{2}$ STEM Enculturation Centre, Faculty of Education, Universiti Kebangsaan Malaysia, UKM, Bangi, Selangor, Malaysia \\ Email: syuhadayunos@gmail.com, rosseni@ukm.edu.my
}

How to cite this paper: Yunos, S., \& Din, R. (2019). The Generation Z Readiness for Industrial Revolution 4.0. Creative Education, 10, 2993-3002. https://doi.org/10.4236/ce.2019.1012223

Received: October 21, 2019

Accepted: November 26, 2019

Published: November 29, 2019

Copyright $\odot 2019$ by author(s) and Scientific Research Publishing Inc. This work is licensed under the Creative Commons Attribution International License (CC BY 4.0).

http://creativecommons.org/licenses/by/4.0/ (c) (7)

Open Access

\begin{abstract}
The Industrial Revolution 4.0 came after the third industrial revolution based on human resource and labour. Currently, the beginning of the Industrial Revolution 4.0 has changed people's daily life and work. Generation $\mathrm{Z}$ are people who were born after the mid-1990s. They are characterized as a smart consumer for technology and are digital natives that will be joining the workforce. They bring new skillsets, high expectations and a desire to disrupt the industry. This quantitative study was conducted to determine the readiness of Generation $\mathrm{Z}$ and their knowledge on the Industrial Revolution 4.0. Data collection was through online Google form distribution using social media platforms such as Whats App to take the opportunity of Generation Z interconnection to cyberspace and their association with frequently using technology. The findings show that the level of knowledge on the present Generation $\mathrm{Z}$ towards Industrial Revolution 4.0 is on a low level but their readiness on the arrival of the Industrial Revolution 4.0 is at a high level. The researchers suggest that Generation $\mathrm{Z}$ is required to increase their knowledge on the issues and information regarding the Industrial Revolution 4.0 by implementing lifelong learning skills because the concept of lifelong learning is an open learning process that gives people the ability to learn and keep learning which mainly based on self-direction. So, these skills are important to help Generation $\mathrm{Z}$ build interest and knowledge for the mainstream.
\end{abstract}

\section{Keywords}

Industrial Revolution 4.0, Knowledge and Willingness, Generation Z, Lifelong Learning Skills

\section{Introduction}

The world has been through three industrial revolutions that started in 1976 un*Part of this paper was presented at International Conference on Global Education VII "Humanising Technology For IR 4.0” on 1-2 July 2019 Padang Panjang, Indonesia. 
til 2010. Before the advent of the Industrial Revolution 4.0, the first revolution is the use of water and steam in producing products. The second revolution using electric power for large-scale manufacturing while the third revolution involves both electric power and information technology to produce automation technology. According to Klaus (2016), we are facing the brink of a technological revolution that will fundamentally change the way we live, work, and interact. This transformation will be unlike anything ever experienced by mankind before as it is characterized by a combination of technologies that blurred the lines between the physical sphere, digital and biology. The Industrial Revolution 4.0, according to Rammel Ramli (2016) statement refers to smart-factories where machines are connected via web access to a system that reflect the whole production chain and make automated decisions.

The Industrial Revolution 4.0 represents the combination of cyber-physical systems, the Internet of Things (IoT) and a system that will create new jobs that may not be relevant to current careers. This revolution was the discovery of various new technologies such as automation, analysis and data highway, simulation, system integration, the use of robots, cloud technology, Internet of things (IoT), and things alike. Advances in automation technology provide new challenges to all sectors in the country and all walks of life need to make changes in line with the digital transformation to remain competitive and boost their progress on the digital landscape. Although this revolution offers new opportunities, many diverse workforces today will be abandoned and not prepare for the future to come (Mohd Fairuz, 2017).

Hence, this has led to growing concerns for business leaders that the global labour force will not be able to follow the changes, in particular, the 1.8 billion youth worldwide who are left behind by the changes. As a high school graduate, lifelong learning skill is a way for an individual to develop their knowledge and skills in various fields that interest them, according to Graham Brown-Martin (2018). In fact, when graduates continue to instill a culture of lifelong learning after graduation, it will help individuals to have an interest in a variety of other disciplines. They will have the ability to learn and re-learn as per required by their job (Ministry of Higher Education, 2018).

The Industrial Revolution 4.0 will change future work and help balance the revenue and income distribution which will reduce economic inequality. Mohamad Raimi (2016) states that it has seen a great revolution that happened in workplaces during the industrial revolution in the first, second and third that had reduced the dependence of raw resources and labour. The emergence of smart factory, autopilot and the robot in the industrial sector will make the work become more focus on process automation through the use of software support (Said, 2017). To pursue this advanced technology, the emergence of Generation $\mathrm{Z}$ was seen as the heir to close the step of the current digital age to make Malaysia undergo the Industrial Revolution 4.0 (Rubaneswaran, 2017).

Higher education experts (Marmolejo, 2017) have argued that the existing knowledge in individuals today only accounts for one percent ahead of the next 
30 years. The job market for the future will be met by individuals or highly skilled workforce that have talent, creative and critical thinking. According to the report from World Economic World (2016), an estimated 65\% of children today who enter primary school will face a new kind of work that has never existed in the present day because of the rapidly growing employment landscape Graham Brown-Martin (2018). Thus, various stakeholders have to be ready to provide future skills and work patterns that will meet the requirements in accordance with the Industrial Revolution 4.0 technology trends.

The study of Ruslin Amir, Hamidun Bunawan \& Mohd Firdaus Yahaya (2018) shows that residential college students will face the challenges of the Industrial Revolution 4.0 which can be divided into several themes, namely the themes of expert thinking skills, career and personal skills, forming a global network and communication. In terms of skills needed to face the Industrial Revolution 4.0 include information skills, high level thinking skills, teamwork skills, communication skills and time management skills to be developed. Reviews from Sharita, Norfidah, and Asmah (2018) showed that the semester four POLIMAS students' knowledge of Industrial Revolution 4.0 is moderate but the study found that student's willingness to take the digital revolution is also at a low level. Research findings (Ladin, 2018) shows that knowledge and the willingness of students in Ipoh university campus towards the Industrial Revolution 4.0 is on a medium level for knowledge while their soft skills on the Industrial Revolution 4.0 is at a high level. Therefore, this study supported empirical studies assessing student's readiness in facing the Industrial Revolution 4.0 in institutions of higher learning.

The advent of automation technology in the Industrial Revolution 4.0 is seen as technological capabilities that do not involve direct human interaction. The industry is also able to overcome the problem of dependence on energy sources that would significantly change the future of the industry, Gizemerboz (2017). The Industrial Revolution 4.0 occurs through three main features of speed, breadth and depth of the impact or the impact of a comprehensive system that has led the world to a future filled with new phenomena such as autonomous car, quantum computing and artificial intelligence, as stated by Klaus Schwab (2016), in his book The Fourth Industrial Revolution which describes the Industrial Revolution 4.0 changing the way we work and live. These changes are driven by three technology domains, namely the physical, digital and biological; spanning nine pillars of the Industrial Revolution 4.0 which includes simulation and virtual reality, system integration, vertical and horizontal, Internet of Things (IoT) industry, cybersecurity, cloud computing, manufacturing additional materials, supply chain, data analysis and robot elections automation. The objectives of this study were two-folds, namely to 1) Identify Generation $Z$ knowledge on the Industrial Revolution 4.0 and 2) evaluate Generation $Z$ readiness on the Industrial Revolution 4.0.

\section{Research Methodology}

A study was conducted to Generation $\mathrm{Z}$ respondents that were born between 
1995 and 2001. According to Cooper and Schindler (2011), the number of respondents sufficient for initial study were between 25 to 100 people, while Johanson and Brooks (2010) also suggests a minimum number of 30 respondents to be reasonable in carrying out a study for the purposes of making a preliminary review or development of a scale or measurement tool. Thus, the researchers set out to study involving 30 respondents who are undergraduate mechanical engineering students at Higher Education Institution. The respondents are the human capital that will meet the challenges in the Industrial Revolution 4.0 during the modernization of various sectors of services, industrial, banking and others. The focus of the study will lead to evaluating the knowledge of Generation $\mathrm{Z}$ on the Industrial Revolution.4.0 and the extent of their readiness. The knowledge construct and willingness construct of Generation $\mathrm{Z}$ towards Industrial Revolution 4.0 are determined using the mean value level. The mean low level is between 0 to 1.6 mean, moderate mean level between 1.7 to 3.3 and the high mean level is between 3.4 to 5.0 (Ladin, 2018).

This study represents the initial survey to determine the knowledge and readiness of Generation $\mathrm{Z}$ to the emergence of the Industrial Revolution 4.0. Researcher has distributed online questionnaires using Google form. Generation $\mathrm{Z}$ is known as the digital generation that prefers to get anything through digital technology and the Internet. Thus, digital platform was used to obtain information from respondents by circulating Google Form link. The questionnaire was adapted from the study of Sharita, Norfidah, and Asmah (2018) for Part A: the profile of respondents. In addition, the study conducted by Norabeerah, Halima and Azlina (2012) was adapted to the questions in section B and C. The questionnaire developed is divided into several parts. Part A which is the respondent profile questions. Part B is the question to research on Generation $\mathrm{Z}$ knowledge on the Industrial Revolution 4.0, while Part $C$ leads to research questions regarding Generation $\mathrm{Z}$ readiness on the Industrial Revolution 4.0. Methods of measurement data are scale type Likert (Likert-type scale), 1) Strongly Disagree (SD), 2) Disagree (D), 3) Agree (A), 4) Strongly Agree (SS).

\section{Instruments Reliability}

This analysis is done to ensure that every question in the survey used is reliable and understood by respondents to answer (Din et al., 2009, 2010, 2011a, 2011b; Din, 2010). It is done through Test-Scale Alpha Reliability Analysis performed on the entire data and test results are shown in Table 1.

Table 1 shows the reliability of the constructs for Generation $\mathrm{Z}$ knowledge of the Industrial Revolution 4.0 is $\alpha=0.801$ (11 items), while Generation Z readiness of the Industrial Revolution 4.0 is $\alpha=0.825$ (10 items). The overall analysis resulted with Cronbach Alpha value of 0.821 for all 21 items. According to Bond and Fox (2015), if the Cronbach alpha coefficient exceeds the coefficient $\alpha>0.7$ then none of them will be eliminated in these constructs. An item in a construct with a low Cronbach Alpha value must be 
Table 1 . Analysis of Reliability with the overall reliability coefficient equal to 0.865 (21 items).

\begin{tabular}{|c|c|c|c|c|c|}
\hline $\begin{array}{c}\text { Cronbach } \\
\text { Alpha }\end{array}$ & Item ID & $\begin{array}{l}\text { Scale Mean if } \\
\text { Item Deleted }\end{array}$ & $\begin{array}{l}\text { Scale Variance if } \\
\text { Item Deleted }\end{array}$ & $\begin{array}{c}\text { Corrected } \\
\text { item-total } \\
\text { correlation }\end{array}$ & $\begin{array}{l}\text { Cronbach alpha } \\
\text { if item deleted }\end{array}$ \\
\hline 0.801 & & & & & \\
\hline \multirow{12}{*}{$\begin{array}{l}\text { Generation } \mathrm{Z} \\
\text { knowledge of } \\
\text { the industrial } \\
\text { revolution } 4.0\end{array}$} & & & & & \\
\hline & B1 & 39.87 & 44,257 & 0.451 & 0.859 \\
\hline & B2 & 40.13 & 45,223 & 0.353 & 0.862 \\
\hline & B3 & 40.03 & 45,206 & 0.321 & 0.863 \\
\hline & B4 & 39.77 & 45,151 & 0.329 & 0.863 \\
\hline & B5 & 39.87 & 43,223 & 0.611 & 0.855 \\
\hline & B6 & 39.83 & 42,971 & 0.656 & 0.853 \\
\hline & B7 & 39.93 & 45,720 & 0.230 & 0.865 \\
\hline & B8 & 39.80 & 45,269 & 0.304 & 0.863 \\
\hline & B9 & 39.90 & 44,093 & 0.475 & 0.859 \\
\hline & B10 & 40.00 & 45,586 & 0.256 & 0.865 \\
\hline & B11 & 39.63 & 44,102 & 0.573 & 0.857 \\
\hline \multirow{11}{*}{$\begin{array}{l}\quad 0.825 \\
\text { Generation } \mathrm{Z} \\
\text { readiness for } \\
\text { industrial } \\
\text { revolution } 4.0\end{array}$} & & & & & \\
\hline & $\mathrm{C} 1$ & 36.57 & 40,806 & 0.765 & 0.847 \\
\hline & $\mathrm{C} 2$ & 36.60 & 41,007 & 0.660 & 0.850 \\
\hline & $\mathrm{C} 3$ & 36.50 & 42,052 & 0.652 & 0.852 \\
\hline & $\mathrm{C} 4$ & 36.57 & 42,806 & 0.568 & 0.855 \\
\hline & $\mathrm{C} 5$ & 37.47 & 42,947 & 0.339 & 0.866 \\
\hline & $\mathrm{C} 6$ & 37.50 & 42,190 & 0.357 & 0.866 \\
\hline & $\mathrm{C} 7$ & 37.20 & 41,959 & 0.445 & 0.860 \\
\hline & C8 & 36.77 & 40,530 & 0.662 & 0.850 \\
\hline & C9 & 37.20 & 43,614 & 0.253 & 0.871 \\
\hline & $\mathrm{C} 10$ & 36.87 & 43,292 & 0.600 & 0.855 \\
\hline
\end{tabular}

removed but the instrument has no items removed. Hence, Table 1 shows that the instrument's reliability is acceptable with a high level of consistency.

\section{Findings}

This study employs descriptive analysis using frequencies and percentages on the background of the respondents. Information of the respondents such as gender, age and semester of study are shown in Table 2.

\subsection{Generation Z Level of Knowledge towards Industrial Revolution}

Referring to Table 3, the overall mean for respondents' knowledge of the Industrial Revolution 4.0 is at a low level. This is because the mean value of the item was low (Item B11: I am willing to cope with the era of the Industrial Revolution 
Table 2. Profile of respondents frequency percent.

\begin{tabular}{ccc}
\hline Demography & Frequency $(\mathrm{N})$ & Percent $(\%)$ \\
\hline Gender & 13 & 43.3 \\
\hline Man & 17 & 56.7 \\
Woman & 30 & 100.0 \\
Number & & \\
\hline Age & 15 & 50.0 \\
\hline $18-20$ & 9 & 30.0 \\
$21-23$ & 6 & 20.0 \\
23 and above & 30 & 100.0 \\
number & & 30.0 \\
\hline Semester & 9 & 60.0 \\
\hline 1 & 18 & 6.7 \\
2 & 2 & 3.3 \\
3 & 1 & 100.0 \\
\hline Number & 30 & \\
\hline & & \\
\hline & & \\
\hline
\end{tabular}

Table 3. Generation $\mathrm{Z}$ findings knowledge of the industrial revolution 4.0.

\begin{tabular}{|c|c|c|}
\hline & Mean & Standard deviation \\
\hline $\begin{array}{l}\text { I know about the simulation and virtual reality technology in the } \\
\text { Fourth Industrial Revolution }\end{array}$ & $1: 47$ & 0.507 \\
\hline $\begin{array}{l}\text { I've seen the technology Internet of Things (IoT) in the Fourth } \\
\text { Industrial Revolution }\end{array}$ & 1.63 & 0.490 \\
\hline $\begin{array}{l}\text { I've heard about cybersecurity technology in the Fourth Industrial } \\
\text { Revolution }\end{array}$ & $1: 37$ & 0.490 \\
\hline $\begin{array}{l}\text { I know that cloud computing technology in the Fourth Industrial } \\
\text { Revolution is a technology that is popular now }\end{array}$ & $1: 47$ & 0.507 \\
\hline $\begin{array}{l}\text { I know of the existence of additive manufacturing (3D PRINTING) in } \\
\text { the Fourth Industrial Revolution }\end{array}$ & $1: 43$ & 0.504 \\
\hline $\begin{array}{l}\text { I know the advantages of system integration technology vertical and } \\
\text { horizontal in the Fourth Industrial Revolution }\end{array}$ & $1: 53$ & 0.507 \\
\hline $\begin{array}{l}\text { I used to use data analysis technology in highway Fourth Industrial } \\
\text { Revolution }\end{array}$ & $1: 40$ & 0.498 \\
\hline $\begin{array}{l}\text { I have seen the use of robot automation technology in the Fourth } \\
\text { Industrial Revolution around me }\end{array}$ & $1: 50$ & 0.509 \\
\hline I know the supply chain is one of the Industrial Revolution Fourth & 1.60 & 0.489 \\
\hline $\begin{array}{l}\text { I know the "Grab", "Waze" is an example of the Fourth Industrial } \\
\text { Revolution technology }\end{array}$ & 1.60 & 0.489 \\
\hline I am willing to cope with the era of the Industrial Revolution Fourth & $1: 23$ & 0.430 \\
\hline Whole & $1: 34$ & 0.45 \\
\hline
\end{tabular}


$4.0(\mathrm{M}=1.23)$ and item B2: I've seen the Internet of things (IoT) technology in the Industrial Revolution 4.0. $(\mathrm{M}=1.63))$.

\subsection{Generation Z Readiness Level on the Industrial Revolution 4.0}

Table 4 shows the construct of the second study, the mean of overall readiness of the Industrial Revolution 4.0 by Generation $\mathrm{Z}$ is at a high-level which is $\mathrm{m}=$ 3.59. Items that have a mean value at a moderate level is C5: Fourth Industrial Revolution technology is not costly $(\mathrm{M}=2.87)$ and item C6: Fourth Industrial Revolution technology does not require the use of a strong Internet $(\mathrm{M}=$ 2.90). While the other 8 items readiness of Generation $Z$ recorded at a high level.

\section{Discussion}

The findings of this study indicate that Generation $\mathrm{Z}$ level of knowledge on the Fourth Industrial Revolution is at a low level, but the level of readiness of the Industrial Revolution 4.0 shows the opposite, namely at a high level. This shows that Generation $\mathrm{Z}$ has more influence or interest in technology but their knowledge about the technology was low. The immediate findings (Sharita, Norfidah, \& Asmah, 2018) and research (Ladin, 2018) which shows the students' knowledge of the Industrial Revolution 4.0 is at a moderate level. Meanwhile, the finding of this study showed Generation $\mathrm{Z}$ readiness of the Industrial Revolution 4.0 at the high level since this era of digital will make the technology not at a high cost and requirement of strong Internet connection will not be a problem. Study by Sharita, Norfidah \& Asmah (2018) showed POLIMAS student readiness of the Industrial Revolution 4.0 is at low level. To educate Generation $\mathrm{Z}$ in understanding Industrial Revolution 4.0, lifelong learning can be applied to learning and teaching sessions in any educational institution or school. The concept of lifelong learning is gaining formal or informal knowledge, skills, and competencies. With diverse new technologies in the Industrial Revolution 4.0 era, individuals are in need of an upgrade and update to their knowledge and skills to face the global challenges, competition, and needs. Industrial Revolution 4.0 is more than just a change driven by technology as it is an opportunity to help everyone, including the leaders, and policymakers from all income groups and countries to take advantage off in creating inclusive and human-centered future technologies. The real opportunity is to go beyond technology and find ways to provide the greatest potential to positively impact on families, organization and community (Gleason, 2018).

\section{Conclusion}

In a nutshell, this study revealed that the Generation $\mathrm{Z}$ knowledge of Industrial Revolution 4.0 is at low level but their willingness to face the Industrial Revolution 4.0 is at a foremost level. Therefore, to increase or gain knowledge of the Industrial Revolution 4.0, the Generation $\mathrm{Z}$ need to adapt or built in the concept 
Table 4. Willingness of generation $\mathrm{Z}$ findings of the industrial revolution 4.0.

\begin{tabular}{|c|c|c|}
\hline & Mean & Standard deviation \\
\hline $\begin{array}{l}\text { Appropriate Fourth Industrial Revolution technology applied to } \\
\text { education }\end{array}$ & 3.83 & 0648 \\
\hline Fourth Industrial Revolution technology helpful to Generation $\mathrm{Z}$ & 3.80 & 0714 \\
\hline $\begin{array}{l}\text { Fourth Industrial Revolution technology assist Generation } \mathrm{Z} \text { in the } \\
\text { learning process and facilitator }\end{array}$ & 3.90 & 0607 \\
\hline $\begin{array}{l}\text { Fourth Industrial Revolution technology makes teaching atmosphere } \\
\text { more fun }\end{array}$ & 3.83 & 0592 \\
\hline Fourth Industrial Revolution technology is not costly & 2.87 & 0860 \\
\hline $\begin{array}{l}\text { Fourth Industrial Revolution technology does not require the use of a } \\
\text { strong Internet }\end{array}$ & 2.90 & 0960 \\
\hline Fourth Industrial Revolution technology is easy to use & $3: 20$ & 0847 \\
\hline $\begin{array}{l}\text { Fourth Industrial Revolution technology will stimulate Generation } \mathrm{Z} \\
\text { interest to focus on the Learning and Facilitation }\end{array}$ & 3.63 & 0765 \\
\hline Fourth Industrial Revolution technology requires no time to master & $3: 20$ & 0925 \\
\hline Fourth Industrial Revolution flexible used of technology & $3: 53$ & 0507 \\
\hline Whole & 3:59 & 0.74 \\
\hline
\end{tabular}

of lifelong learning. This in turn will increase knowledge of the technology as a measure to explore and understand more of the Industrial Revolution 4.0. In additional, future study about the skill needed for the Industrial Revolution 4.0 would be a great research study in this field to be explored by the other researchers.

\section{Acknowledgements}

This research was funded by the Faculty of Education, Universiti Kebangsaan Malaysia with research code GG-2019-046 \& PP-FPEND-2019.

\section{Conflicts of Interest}

The authors declare no conflicts of interest regarding the publication of this paper.

\section{References}

Amir, R., Bunawan, H., \& Yahaya, M. F. (2018). Cabaran Mahasiswa dan Kolej Kediaman Mendepani Revolusi Industri 4.0. Governans, Institusi \& Pengurusan Kewangan. Prosiding Konvensyen Kepengetuaan dan Felo Penghuni Kolej Kediaman Universiti Awam Kebangsaan 2018.

Bond, T. G., \& Fox, C. M. (2015). Applying the Rasch Model Fundamental Measurement in the Human Sciences. In Routledge, T., \& Group, F. (Eds.), Third Edition. New York \& London.

Brown-Martin, G. (2018). Education and the Fourth Industrial Revolution (Learning to Thrive in a Transforming World). In 11th annual International Conference of Education, Research and Innovation (p. 7270). Seville, Spain. 
https://doi.org/10.21125/iceri.2018.2771

https://medium.com/learning-re-imagined/education-and-the-fourth-industrial-revolu $\underline{\text { tion-cd6bcd7256a3 }}$

Din, R. (2010). Development and Validation of an Integrated meaningful Hybrid E-Training (I-met) for Computer Science: Theoretical-Empirical Based Design and Development Approach. PhD Thesis. Bangi: Universiti Kebangsaan Malaysia.

Din, R., Faisal, M. K. Z., Shah, P. M., Rahman, S., Karim, A. A., Omar, R., Lubis, M. A., Nordin, M. S., Zakaria, M. S., \& Anwar, K. A. (2011a). Restructuring of the E-Learning Styles Factors for Technology Training. World Applied Sciences Journal, 14, 44-50.

Din, R., Nordin, M. S., Abu N. L. K, Ahmad, T. B. T., Jusoff, K. J., Johar, N. A., Faisal M. K. Z., Zakaria, M. S., Ahmad, M., Karim, A. A., \& Mastor, K. A. (2010). Development and Validation of Meaningful Hybrid E-Training Model for Computer Education. International Journal of Computer Science and Information Technologies (IJCSIT), 1, 179-184.

Din, R., Zakaria, M. S., Mastor, K. A. Mastor, Razak, N. A., Embi, M. A., \& Ariffin, S. R. (2009). Meaningful Hybrid E-Training Model via POPEYE Orientation. WSEAS International Journal of Education and Information Technologies, 3.

Din, R., Zakaria, M. S., Nordin, M. S., Faisal, M. K. Z., Abu, N. L. K., Ahmad, T. B. T., Mastor, K. A., Karim, A. A., \& Emb, M. A. (2011b). A Meaningful Hybrid E-Training Measure for Technology in Educaion. Asian Journal in Teaching and Learning in Higher Education, 3, 71-82.

Erboz, G. (2017). How to Define Industry 4.0: Main Pillars of Industry 4.0. In 7th International Conference on Management. Nitra: Slovakia. https://www.researchgate.net/publication/326557388 How To Define Industry 40 Main Pillars Of Industry 40

Fairuz, M. M. Y. (2017). Fourth Industrial Revolution/Industry 4.0/4.0 Ir. https://www.academia.edu/38342865/IR401.docx

Gleason, N. W. (2018). Singapore's Higher Education Systems in the Era of the Fourth Industrial Revolution: Preparing Lifelong Learners. In N. W. Gleason (Ed.), Higher Education in the Era of the Fourth Industrial Revolution (pp. 145-169). Berlin: Springer. https://doi.org/10.1007/978-981-13-0194-0

Johanson, G. A., \& Brooks, G. P. (2010). Initial Scale Development: Sample Size for Pilot Studies. Educational and Psychological Measurement, 70, 394-400. https://doi.org/10.1177/0013164409355692

Ladin, I. C. A. (2018). Pengetahuan dan Kesediaan Revolusi Industri 4.0 Dalam Kalangan Pelajar Institusi Pendidikan Guru Kampus Ipoh. Online Journal of Islamic Education, 6, 9. (In Malay)

Ministry of Higher Education (2018). Framing Malaysian Higher Education 4.0: Future-Proof Talent. Putrajaya: Ministry of Higher Education Malaysia.

Norabeerah, S., Halima, B. Z., \& Azlina, A. (2012). Pengajaran masa depanmenggunakanteknologi augmented reality dalampendidikan Bahasa Melayu: Tahapkesedaran guru. Jurnal Pendidikan Bahasa melayu; Malay Language Education (MyLEJ), 2, 1-10. (In Malay)

Ramli, R. (2017). The Industrial Revolution 4.0-Did AI Robots Take Over? https://otakit.my/revolusi-industri-4-0-adakah-robot-ai-akan-ambil-alih

Said, D. S. (2017). People Need to Be Ready to Face the Industrial Revolution 4.0-Salleh (pp. 1-7).

Schwab, K. (2016). The Fourth Industrial Revolution. Geneva: World Economic Forum. 
Sharita, A. G., Norfidah, A. H., \& Asmah, O. (2018). Kajian Mengenai Kesediaan Pelajar Semester Empat Polimas Dalam Mengharungi Cabaran Revolusi Industri 4.0. In National Competition through Innovation and Invention Exhibition. Polimas, Kedah. (In Malay)

https://upikpolimas.edu.my/conference/index.php/icompex/icompex 2018/paper/view File/461/263 